\title{
Expression level of miRNAS in patients with gestational diabetes
}

\section{[Gestasyonel Diyabet Hastalarinda miRNA Ekspresyon Düzeyleri]}

https://doi.org/10.1515/tjb-2019-0157

Received April 22, 2019; accepted June 12, 2020;

published online November 2, 2020

\begin{abstract}
Background: Gestational diabetes mellitus (GDM), which has been identified for the first time during pregnancy and is defined as glucose intolerance of varying degrees, is one of the prediabetes states that are at risk for developing type 2 diabetes. MicroRNAs (miRNAs) are associated with pregnancy complications and are even necessary for the regulation of pancreatic development and glucose-induced insulin secretion. This study aims to investigate miRNAs expressed in maternal plasma to detect the availability as a biomarker in the diagnosis of GDM.
\end{abstract}

Methods: In this study, 30 pregnant women with GDM diagnosed according to GDM American Diabetes Association criteria and 30 healthy pregnant women were included and miRNA expression levels were investigated.

*Corresponding author: Senay Balci, PhD, Mersin University Medical Faculty, Department of Medical Biochemistry, Mersin, 33079, Turkey, Phone: +90 532300 8970, +90 32436106 84, Fax: +90 3243412400 , E-mail: sbfidanci@hotmail.com. https://orcid.org/0000-0002-7498$604 X$

Aysegul Gorur and Lulufer Tamer, Mersin University Medical Faculty, Department of Medical Biochemistry, Mersin, Turkey,

E-mail: aysegulgorur82@gmail.com (A. Gorur), lutamer@yahoo.com (L. Tamer). https://orcid.org/0000-0002-8463-8663 (A. Gorur), https://orcid.org/0000-0002-0997-0260 (L. Tamer)

Didem Derici Yıldırım, Mersin University Medical Faculty, Department of Biostatistics and Medical Informatics, Mersin, Turkey, E-mail: didemderici@hotmail.com. https://orcid.org/0000-00017709-6133

Filiz Cayan, Mersin University Medical Faculty, Department of Gynecology and Obstetrics, Mersin, Turkey,

E-mail: filizcayan@yahoo.com
Circulating 39 miRNAs were analyzed by qRT-PCR using 96.96 Dynamic Array IFCs.

Results: The findings showed that the expression level of miR-7-5p significantly upregulated when compared with healthy pregnant women with gestational diabetes (fold change:2.3, $\mathrm{p}<0.05)$.

Conclusions: There is controversy about what is the most appropriate test for GDM screening. Therefore, supported by further studies, miR-7-5p can be used for the diagnosis of GDM.

Keywords: Biomarker; GDM; miRNA; Pregnancy.

\section{öz}

Amaç: Gebelikte değişen derecelerde glikoz intoleransı olarak tanımlanan gestasyonel diabetes mellitus (GDM), tip two diyabet oluşturma riski bulunduran prediyabet durumlarından biridir. Pankreas gelişimi ve glikoza bağlı insülin sekresyonunun düzenlenmesinde rol alan mikroRNA'lar (miRNA'lar), aynı zamanda gebelik ile ilgili komplikasyonlar ile de ilişkilidirler. Bu çalışmanın amacı, maternal plazmada ifade edilen miRNA'ların GDM tanısinda kullanılabilirliğini tespit etmektir.

Yöntemler: Çalışmaya, Amerikan Diyabet Derneği kriterlerine göre GDM tanısı alan 30 gebe ve 30 sağlıklı gebe dahil edildi ve miRNA ekspresyon düzeyleri araştırıldı. Dolaşımdaki 39 miRNA'nın analizi, 96.96 Dynamic Array IFCs kullanılarak qRT-PCR cihazında gerçekleştirildi.

Bulgular: Sağlıklı gebeler ile karşılaştırıldığında, GDM'li gebelerde miR-7-5p'nin ekspresyon düzeyinin, anlamlı derecede artmış olduğu bulundu (kat değişimi: 2.3, p<0.05). Sonuç: GDM taramasında yapılan testlerin uygulanması konusunda fikir ayrılıkları mevcuttur. Bu testlerin dışında, ileri çalışmalarla desteklenen miR-7-5p'nin, GDM tanısında kullanılabileceğini düşünmekteyiz.

Anahtar kelimeler: biyobelirteç; GDM; gebelik; miRNA. 


\section{Introduction}

Gestational diabetes mellitus (GDM) is glucose intolerance at various grades that first occurred in pregnancy. Although GDM is one of the most common perinatal complications, the risk of other pregnancy complications, such as pregnancy hypertension and diabetic ketoacidosis, are high in these pregnant women. There is also a high likelihood of having type 2 diabetes after pregnancy. GDM is characterized by peripheral (adipose tissue, skeletal muscle, and liver) insulin resistance. In pregnancy, deterioration in glucose tolerance and peripheral resistance to insulin are in parallel with increasing hormones. Insulin resistance may be tolerated in most pregnant women, while a small part does not have adequate adaptation and GDM occurs. This adaptation is attempted to provide increased insulin synthesis in the islets of the pancreas, increased insulin secretion due to glucose, increase in pancreatic beta-cell mass, glucose metabolism and increased cAMP metabolism [1-4]. GDM is also associated with an increased risk of short and long-term complications in the fetus, as well as risk for the mother. Polyhydramnios, urinary tract infections, neonatal hypoglycemia and postpartum hemorrhage can be seen in GDM. In addition, in the postnatal period, rapid growth rate, adolescent obesity, diabetes or impaired glucose tolerance and nerve damage may occur $[5,6]$.

Several studies have demonstrated that the abnormal expression of miRNA is associated with pregnancy complications. This suggested the potential use of miRNAs as a prognostic indicator of pregnancy-specific diseases, especially preeclampsia and GDM $[7,8]$. In recent decades, miRNAs have been shown to be stable in circulation and potential for the diagnosis and prognosis of several diseases. miRNAs regulated gene expression and play critical roles in many biological processes, such as development, differentiation, apoptosis, oncogenesis, metabolic homeostasis and DNA methylation. miRNAs also functions in glucose homeostasis and insulin production and secretion [8-10]. miRNAs is one of several factors necessary for the regulation of glucose-stimulated insulin secretion and pancreatic development [11].

MicroRNAs are stable in tissue and body fluids, suggesting that they can be used as potentially non-invasive blood-based biomarkers. Hence, many studies have been conducted in recent years and many data have been obtained showing that various profiles of circulating free microRNAs are bound to many pathological processes [12]. The diagnosis of GDM, which can be diagnosed in the later stages of pregnancy, which may have significant complications both for the mother and the fetus, is significant in the early gestational weeks. Thus, in this study, we aimed to investigate the role of 39 miRNAs expressed in maternal plasma and reported to be associated with diabetes, glucose metabolism and insulin resistance in the diagnosis of GDM.

\section{Materials and methods}

In this study, 60 pregnant women who were examined at Mersin University in the Obstetrics and Gynecology Department between September 2013 and March 2014 were included. During the routine examinations, the pregnant women underwent a $75 \mathrm{~g}$ oral glucose tolerance test (OGTT) for $2 \mathrm{~h}$. GDM was diagnosed according to American Diabetes Association criteria [13]. Thirty pregnant women with GDM were included in the patient group, while 30 healthy pregnant women who had normal glucose tolerance were included in the control group in this study.

Pregnant women, who accepted to give blood samples, were at 24-28 gestational week. They had a single pregnancy, non-obesity, no history of diabetes and not used any drugs other than pregnancyrelated drugs were included in this study. In addition, exclusion criteria for both groups were determined as follows: hypertension disorders, smoking and alcohol use, thyroid disorders or fetal congenital anomalies. The ages of the pregnant women in the patient and control groups were matched to show that the difference in miRNA expression levels was not related to an age-related cause.

Determination of the HbA1c in whole blood was performed using Cobas Integra 800 automated analyzer by the turbidimetric inhibition immunoassay method of hemolyzed whole blood samples.

miRNA expression analyses were performed according to the method used in our previous study [14]. Patients and control groups' peripheral blood was collected to tubes with EDTA. Samples were centrifuged at $2700 \mathrm{~g}$ for $15 \mathrm{~min}$; plasma was taken to a sterile microcentrifuge tube then centrifuged again at $13000 \mathrm{~g}$ for $10 \mathrm{~min}$. Plasma samples stored at $-80^{\circ} \mathrm{C}$ until RNA isolation (about three months). Total RNA was isolated using the High Pure miRNA Isolation Kit (Roche). In this study, the optimum rate accepted for pure RNA was 2.0 and the quality of the RNA was measured using the NanoDrop Spectrophotometer (Thermo Scientific, USA) according to the manufacturer's protocols. Then, RNA was converted into cDNA using Reverse Transcriptase according to the manufacturer's instructions. Reverse transcription and then pre-amplification (TaqMan, PreAmp Master Mix 29), in the analysis of real-time PCR system (LightCycler 480; Roche) were used, and 39 miRNAs were analyzed with high-throughput realtime quantitative PCR (RT-qPCR) device (Fluidigm; Biomark) using 96.96 Dynamic Array Integrated Fluidic Circuits (IFCs).

The distribution hypothesis was tested by the Shapiro Wilk test. Normally distributed, continuous variables were presented as mean \pm standard deviation, but without assumption, the data were summarized in median [25-75\%]. In the comparison of the two groups, the Independent Sample t-test was used for normal distribution and the Mann-Whitney U-test was used for the distribution is non-normal. $\mathrm{p}<0.05$ was accepted as the level of statistical significance. The analysis was performed in Statistica v.13.3.1.

miRNA expression statistical analyses were performed using the Biogazelle's qbase PLUS2.4 software. Since there were no validated 
Table 1: Characteristics of the study population.

\begin{tabular}{lrrr}
\hline Characteristic & No GDM (n=30) & GDM (n=30) & p-Value \\
\hline Age, years & 29.9 & 32.3 & 0.07 \\
Gestation, weeks & 27.4 & 26.9 & 0.30 \\
Fasting glucose, mg/dL & 84.2 & 100.7 & 0.02 \\
1-h Glucose, $\mathrm{mg} / \mathrm{dL}$ & 128.4 & 191.3 & 0.0001 \\
2-h Glucose, $\mathrm{mg} / \mathrm{dL}$ & 107.7 & 153.5 & 0.0003 \\
HbA1c, \% & 5.2 & 5.6 & 0.01 \\
\hline
\end{tabular}

housekeeping genes that could be used for normalization, the global mean normalization method was used in the analysis of circulating miRNA expression [15]. The fold changes were calculated to investigate the difference in miRNA expression value between the two groups. Fold-Change $2^{-\Delta \Delta C T}$ is the normalized miRNA expression $\left(2^{-\Delta C T}\right)$ in the patient group divided the normalized miRNA expression $\left(2^{-\mathrm{CCT}}\right)$ in the control group. Fold-Regulation represents fold-change results in a biologically meaningful way. $\mathrm{p}<0.05$ was considered statistically significant.

The study protocol was approved by the local Ethical Committee (22.08.2013, 2013/261), and written informed consent was obtained from all participants before data collection.

\section{Results}

\section{Participant characteristics}

In this study, blood samples from 30 women with GDM and 30 healthy pregnant women were assessed. The characteristics of the participant are given in Table 1 . The findings showed that there was no significant difference in age between the control group and pregnant women with GDM. As expected, compared with healthy pregnant women, pregnant women with GDM had higher fasting glucose, $1 \mathrm{~h}$ glucose, 2h-glucose and HbA1c.

\section{MicroRNA profiling}

In this study, the expression levels of 39 different miRNAs were analyzed. We searched articles indexed in PubMed (MEDLINE) database using Title/Abstract words ("microRNA" or "miRNA" and "diabetes") and mirbase.

In this study, 26 miRNAs were downregulated and 13 miRNAs were upregulated in GDM pregnant women when compared with healthy pregnant women. However, there was no statistically significant increase or decrease in any of the 38 miRNAs in GDM pregnant women compared to the control group. Table 2 is given with these miRNAs and associated tissues.

Among the 39 miRNAs analyzed, only miR-7-5p was significantly upregulated in pregnant with GDM when compared to healthy pregnant (fold change: 2.3, fold
Table 2: Analyzed microRNAs in related tissues.

\begin{tabular}{|c|c|c|}
\hline Tissue & Downregulated & Upregulated \\
\hline \multirow[t]{12}{*}{ Pancreas } & $\operatorname{miR}-124-3 p$ & miR-128 \\
\hline & $\operatorname{miR}-125 b-5 p$ & miR-129-5p \\
\hline & miR-137 & miR-17-5p \\
\hline & miR-139-5p & $\operatorname{miR}-34 c-5 p$ \\
\hline & miR-152 & miR-7-5p \\
\hline & $\operatorname{miR}-210$ & - \\
\hline & $\operatorname{miR}-24-3 p$ & - \\
\hline & miR-375 & - \\
\hline & miR-486-5p & - \\
\hline & miR-9-5p & - \\
\hline & miR-16-1-3p & - \\
\hline & $\operatorname{miR}-26 b-3 p$ & - \\
\hline \multirow[t]{2}{*}{ Pancreas, liver } & miR-214-3p & miR-191-5p \\
\hline & miR-29a-3p & miR-29b-3p \\
\hline \multirow[t]{2}{*}{ Liver } & miR-328 & miR-384 \\
\hline & $\operatorname{miR}-222-5 p$ & - \\
\hline \multirow[t]{2}{*}{ Pancreas, adipose } & $\operatorname{miR}-126-5 p$ & - \\
\hline & $\operatorname{miR}-21-3 p$ & - \\
\hline \multirow[t]{2}{*}{ Adipose } & miR-132-3p & - \\
\hline & miR-198 & - \\
\hline Liver, adipose & miR-107 & miR-143-5p \\
\hline Skeletal muscle & miR-133b & miR-1 \\
\hline \multirow[t]{3}{*}{ Pancreas, circulating } & miR-302b-3p & miR-301b \\
\hline & miR-182-5p & - \\
\hline & miR-197-3p & - \\
\hline \multirow[t]{2}{*}{ Circulating } & miR-218-5p & miR-342-3p \\
\hline & - & miR-142-3p \\
\hline
\end{tabular}

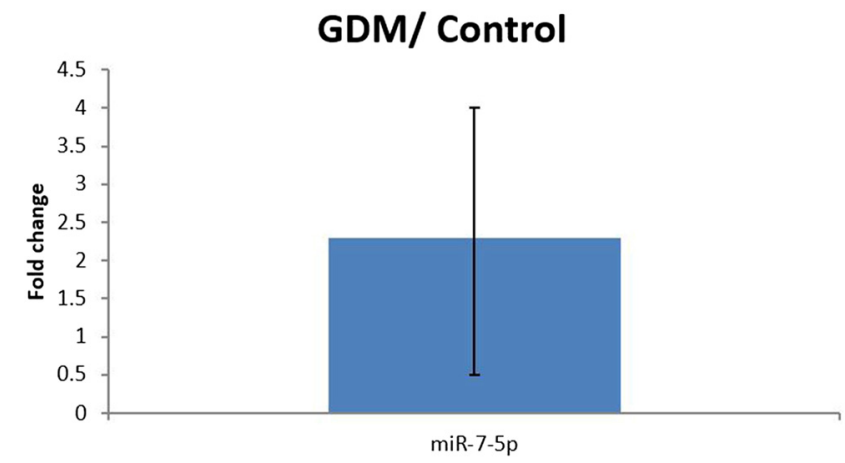

Figure 1: miR-7-5p which is upregulated in pregnant women with gestational diabetes compared to healthy pregnant women.

regulation: 2.3, $\mathrm{p}=0.02$ ) (Figure 1). The expression of all miRNAs in pregnant with GDM compared to controls is shown in Table 3.

\section{Discussion}

GDM is a serious worldwide problem that needs to be addressed urgently, considering severe complications for 
Table 3: MicroRNA expression in maternal plasma in pregnant women with gestational diabetes mellitus compared to healthy pregnant women.

\begin{tabular}{|c|c|c|c|}
\hline miRNA & Fold change & Fold regulation & p-Value \\
\hline miR-1 & 2.11 & 2.11 & 0.30 \\
\hline miR-107 & 0.61 & -1.64 & 0.19 \\
\hline miR-124-3p & 0.74 & -1.35 & 0.35 \\
\hline miR-125b-5p & 0.50 & -2.01 & 0.90 \\
\hline miR-128 & 1.15 & 1.15 & 0.44 \\
\hline miR-129-5p & 1.02 & 1.02 & 0.96 \\
\hline miR-132-3p & 0.15 & -6.86 & 0.09 \\
\hline miR-133b & 0.93 & -1.07 & 0.36 \\
\hline $\operatorname{miR}-137$ & 0.71 & -1.40 & 0.35 \\
\hline miR-139-5p & 0.57 & -1.76 & 0.18 \\
\hline miR-142-3p & 2.31 & 2.31 & 0.47 \\
\hline miR-152 & 0.26 & -3.85 & 0.45 \\
\hline $\operatorname{miR}-17-5 p$ & 1.30 & 1.30 & 0.35 \\
\hline miR-182-5p & 0.88 & -1.13 & 0.35 \\
\hline miR-191-5p & 1.21 & 1.21 & 0.83 \\
\hline miR-197-3p & 0.83 & -1.20 & 0.77 \\
\hline miR-198 & 0.70 & -1.44 & 0.35 \\
\hline $\operatorname{miR}-210$ & 0.61 & -1.63 & 0.95 \\
\hline $\operatorname{miR}-214-3 p$ & 0.65 & -1.53 & 0.79 \\
\hline miR-218-5p & 0.94 & -1.06 & 0.78 \\
\hline miR-24-3p & 0.90 & -1.11 & 0.96 \\
\hline miR-29a-3p & 0.43 & -2.35 & 0.98 \\
\hline miR-29b-3p & 1.23 & 1.23 & 0.30 \\
\hline miR-301b & 1.49 & 1.49 & 0.15 \\
\hline miR-302b-3p & 0.39 & -2.55 & 0.35 \\
\hline $\operatorname{miR}-328$ & 0.21 & -4.84 & 0.26 \\
\hline miR-342-3p & 1.10 & 1.10 & 0.25 \\
\hline$m i R-34 c-5 p$ & 1.17 & 1.17 & 0.31 \\
\hline miR-375 & 0.10 & -9.81 & 0.43 \\
\hline miR-384 & 1.97 & 1.97 & 0.30 \\
\hline miR-486-5p & 0.80 & -1.25 & 0.35 \\
\hline miR-9-5p & 0.52 & -1.92 & 0.35 \\
\hline miR-126-5p & 0.95 & -1.05 & 0.64 \\
\hline miR-143-5p & 5.54 & 5.54 & 0.51 \\
\hline $\operatorname{miR}-16-1-3 p$ & 0.79 & -1.26 & 0.77 \\
\hline $\operatorname{miR}-21-3 p$ & 0.71 & -1.41 & 0.53 \\
\hline miR-222-5p & 0.12 & -8.56 & 0.96 \\
\hline miR-26b-3p & 0.66 & -1.51 & 0.58 \\
\hline miR-7-5p & 2.29 & 2.29 & 0.02 \\
\hline
\end{tabular}

both mother and fetus [16]. Although there is no standardized method for GDM screening and diagnosis, OGTT is widely used in clinical practice [17]. Recent studies have shown that miRNA expression, downregulated or upregulated, is associated with pregnancy complications and suggests the potential use of prognostic markers of pregnancy-specific diseases, such as GDM $[6,7]$. Previous studies have reported that serum or plasma miRNAs are differentially expressed between GDM patients and controls. A study has reported that miRNA profiles of peripheral blood mononuclear cells isolated GDM patients have identified 10 miRNA (miR-26a, miR-101, miR-181a, miR-181d, miR-1268, miR-29a, miR-29c, miR-30b, miR-1180, and miR-595) that seemed to be specific for GDM [18]. Another study has found that plasma miRNAs are differentially expressed in GDM. Differential expression of five upregulated miRNAs (hsa-miR-16-5p, hsa-miR-17-5p, hsa-miR-19a-3p, hsa-miR-19b-3p, hsa-miR-20a-5p) have been aberrantly expressed before serum glucose abnormality [6]. However, Cao et al., in their study, have analyzed the same miRNAs in a larger number of patient populations and have not found the same results at the end of the analysis. Some studies have reported that miR-17-5p and miR-16-5p are associated with type 2 diabetes mellitus and other metabolic diseases. However, the role of these up-regulated microRNAs in the pathogenesis of GDM is not yet fully understood [19]. Tagoma et al. have reported that miR-195-5p has shown the highest fold upregulation in GDM and targeted the highest number of genes important in fatty acid metabolism [20]. In another study of South African women with GDM, researchers have investigated whether the circulating miRNAs with non-invasive biomarker potential for GDM have changed in serum. According to the researchers, miR-20a-5p and miR-222-3p have been significantly down-regulated in women with GDM compared to controls [21].

In this study, according to the study data, miR-7-5p expression in pregnant and GDM patients was determined to be upregulated by age-matched pregnant women. Recent data have suggested that during human pancreatic development, miR-7, which is a pancreatic islet, specific miRNA expressed at high levels [22, 23].

In humans, $\beta$-cell differentiation or phenotype loss in the pathogenesis of diabetes has been noted as a new mechanism of action of cell dysfunction [24]. As in vitro studies, researchers have reported that natural pancreatic islets from donors with non-diabetic lead to the formation of an undifferentiated cell population. The role of miRNAs in this mechanism is considered another important issue. Sebastiani et al. in their in vitro studies have investigated miRNA expression levels in dissociated islet cells compared to mature pancreatic islets and have found that 13 miRNA up-regulated and 110 miRNA down-regulated. Researchers argue that these down-regulated miRNAs, particularly expressed in islets and $\beta$-cells, the target gene is disallowed that are responsible for the maintenance of the endocrine-pancreatic phenotype, and therefore have cell responses or phenotypic changes. On the other hand, upregulated 13 miRNAs have been reported to be biomarkers of new islet cells and to target genes that eliminate differentiation or participate in pancreatic cell functions. 
In particular, the importance of these target genes, which is thought to play a role in cell-cell signalling or adhesion, is also emphasized [25]. However, in other studies, miR-7, miR-9, miR-375 have been shown to be important in controlling $\beta$-cell function $[26,27]$.

Apart from its importance in differentiation and proliferation in the pancreatic $\beta$-cell, miR-7 modulates the release of insulin granules, while miR-7 does not affect the total number of insulin granules per cell [28].

The insulin receptor substrate 1 (IRS-1) acts as a key molecule by transmitting signals from the INSR to downstream enzymes in the insulin signal pathway in the peripheral tissues. Low levels of IRS-1 expression in human skeletal muscles indicate that down-regulation of IRS-1 is associated with IR and T2DM [29]. Similarly, in another cellular IR model study, overexpression of miR-7 downregulates IRS-1 expression by binding to $3^{\prime}$-UTR has been demonstrated [30]. In other studies, overexpression of miR-7 was responsible for downregulated IRS1 expression, as well as inhibiting insulin-induced Akt phosphorylation and glucose uptake [29].

When the differentiation process of human pluripotent stem cells (hPSCs) into insulin-producing cells (IPCs) was examined, it was reported that in vitro differentiation of hPSCs was four stages. These stages were as follows: endoderm formation (0-4 days), induction of pancreatic progenitor cells (PPCs) (5-9 days), expansion of PPCs (1015 days) and formation of IPCs (16-25 days). Based on this model, the expression level of miRNAs thought to modulate the process of directing hPSC differentiation into isletlike cell clusters was investigated. In this process, four islet-specific miRNAs (miR-7, miR-375, miR-34a and miR-146a) exhibit different expression patterns. miR-375 and miR-7 increase from day 4, peak at day 8 , and then decrease to the end of differentiation. In contrast, miR-146a decreases during the differentiation process, and miR-34a expression initially decreases, followed by restoration on day 21. Further, it has been demonstrated that miR-375 directly targets HNF1 $\beta$ and overexpression of miR-375 lowers the protein level of HNF1 $\beta$ [31]. However, in another study with MiR-375-null mice, it was found that increased total pancreatic $\alpha$ cell numbers and plasma glucagon levels, and accordingly increased gluconeogenesis and hepatic glucose output. As a result, lacking miR-375 mice were reported to be hyperglycemic [9]. While miR-7 directly targets PAX6, overexpression of miR-7 has also been reported to reduce the level of expression of PAX6 [31].

A study has shown that between 8 and 12 weeks of the gestational week (wga), the level of miR-7 expression is very low and the expression of miR-7 is increasing by the 13th wga. In addition, their findings showed that miR-7 expression levels have remained high up to 18 wga and started to decrease in the following weeks [22]. Recently, researchers reported that this miRNA plays a critical role in the allocation of islet cell fate and is also significant in $\beta$-cell function. Indeed, recent overexpression or deletion of miR-7 by transgenic or knockout routes leads to respective suppression or promotion of differentiation of $\alpha$ and $\beta$-cells. This is apparently Ngn3 induces endocrine cell differentiation by affecting the expression of Pax6, a key transcription factor gene [32].

In summary, many studies have produced evidence that the abnormal expression of circulating miRNA is associated with pregnancy complications. However, people from different countries appear to have different miRNA profiles in the same metabolic condition. We should note that there is a lack of data on the expression of circulating serum/plasma microRNAs in GDM. In recent studies, different miRNAs for GDM have been reported to be a candidate biomarker [33,34], which is the cause of the discordant in the data, possibly analyzing different samples and the different processing protocols used $[19,35]$.

\section{Conclusion}

Studies showed that GDM caused a reduction of pancreatic $\beta$-cell expansion in pregnancy and the serum-based screening for GDM typically begins at 24-28 weeks of gestation and the testing process may not be completed until 32 weeks [36]. The findings obtained in this study showed that miR-7, which was expressed in pancreatic adult and fetal endocrine cells was upregulated in GDM patients when compared to healthy pregnant women. Based on our findings, specific miRNAs can be used as a potential biomarker for early diagnosis of the GDM because of the limited time for intervention and management of GDM. However, despite their stability and ease of analysis, there are many analytical and pre-analytical challenges that need to be addressed before the clinical use of circulating miRNAs. Standardization of pre-analytical and analytical methods may increase reproducibility between studies [35]. In addition, large prospective cohort studies should be performed to investigate factors affecting miRNA expression and identify whether they may be diagnostic or prognostic candidates.

Acknowledgments: IFCC WorldLab Istanbul was published as abstracts in 2014.

Research funding: This research project was partially supported by Mersin University Scientific Research Projects Unit under grant number BAP-TF TTB (LT) 2014-1 GP. 
Author contributions: All authors have accepted responsibility for the entire content of this manuscript and approved its submission.

Competing interests: Authors state no conflict of interest. Informed consent: Informed consent was obtained from all individuals included in this study.

Ethical approval: The study protocol was approved by the local Ethical Committee (22.08.2013, 2013/261), and written informed consent was obtained from all participants before data collection.

\section{References}

1. Rice GE, Illanes SE, Mitchell MD. Gestational diabetes mellitus: a positive predictor of type 2 diabetes. Int J Endocrinol 2012;2012. https://doi.org/10.1155/2012/721653.

2. Petry CJ. Gestational diabetes: risk factors and recent advances in its genetics and treatment. Br J Nutr 2010;104:775-87.

3. Wang X, Li W, Ma L, Gao J, Liu J, Ping F, et al. Association study of the miRNA-binding site polymorphisms of CDKN2A/B genes with gestational diabetes mellitus susceptibility. Acta Diabetol 2015; 52:951-8.

4. Shi Z, Zhao C, Guo X, Ding H, Cui Y, Shen R, et al. Differential expression of microRNAs in omental adipose tissue from gestational diabetes mellitus subjects reveals miR-222 as a regulator of $E R \alpha$ expression in estrogen-induced insulin resistance. Endocrinology 2014;155:1982-90.

5. Liang Z, Dong M, Cheng Q, Chen D. Gestational diabetes mellitus screening based on the gene chip technique. Diabetes Res Clin Pract 2010;89:167-73.

6. Zhu Y, Tian F, Li H, Zhou Y, Lu J, Ge Q. Profiling maternal plasma microRNA expression in early pregnancy to predict gestational diabetes mellitus. Int J Gynaecol Obstet 2010;130:49-53.

7. Zhao Z, Moley KH, Gronowski AM. Diagnostic potential for miRNAs as biomarkers for pregnancy-specific diseases. Clin Biochem 2013;46:953-60.

8. Kumar M, Nath S, Prasad HK, Sharma GD, Li Y. MicroRNAs: a new ray of hope for diabetes mellitus. Protein Cell 2012;3:726-38.

9. Poy MN, Hausser J, Trajkovski M, Braun M, Collins S, Rorsman P, et al. miR-375 maintains normal pancreatic $\alpha$ - and $\beta$-cell mass. Proc Natl Acad Sci USA 2009;106:5813-18.

10. Laganà AS, Vitale SG, Sapia F, Valenti G, Corrado F, Padula F, et al. miRNA expression for early diagnosis of preeclampsia onset: hope or hype? J Matern Fetal Neonatal Med 2017;5:1-5.

11. Lynn FC, Skewes-Cox P, Kosaka Y, McManus MT, Harfe BD. MicroRNA expression is required for pancreatic islet cell genesis in the mouse. Diabetes 2007;56:2938-45.

12. Mitchell PS, Parkin RK, Kroh EM, Fritz BR, Wyman SK, PogosovaAgadjanyan EL, et al. Circulating microRNAs as stable blood-based markers for cancer detection. Proc Natl Acad Sci USA 2008;105: 10513-8.

13. American Diabetes A. Diagnosis and classification of diabetes mellitus. Diabetes Care 2010;33(1 Suppl):62-9.

14. Balci S, Ayaz L, Gorur A, Yildirim HY, Akbayir S, Dogruer Unal N, et al. microRNA profiling for early detection of nonmelanoma skin cancer. Clin Exp Dermatol 2016;41:346-51.
15. Mestdagh P, VanVlierberghe P, DeWeer A, Muth D, Westermann F, Speleman $F$, et al. A novel and universal method for microRNA RT-qPCR data normalization. Genome Biol 2009;10:1-10.

16. Santangelo C, Zicari A, Mandosi E, Scazzocchio B, Mari E, Morano $\mathrm{S}$, et al. Could gestational diabetes mellitus be managed through dietary bioactive compounds? Current knowledge and future perspectives. Br J Nutr 2016;115:1129-44.

17. Tieu J, Middleton P, McPhee AJ, Crowther CA. Screening and subsequent management for gestational diabetes for improving maternal and infant health. Cochrane Database Syst Rev 2014;2. https://doi.org/10.1002/14651858.CD007222.pub3.

18. Collares CV, Evangelista AF, Xavier DJ, Rassi DM, Arns T, Foss-Freitas MC, et al. Identifying common and specific microRNAs expressed in peripheral blood mononuclear cell of type 1 , type 2 , and gestational diabetes mellitus patients. BMC Res Notes 2013;26:491.

19. Guarino E, Delli Poggi C, Grieco GE, Cenci V, Ceccarelli E, Crisci I, et al. Circulating MicroRNAs as biomarkers of gestational diabetes mellitus: updates and perspectives. Internet J Endocrinol 2018; 2018. https://doi.org/10.1155/2018/6380463.

20. Tagoma A, Alnek K, Kirss A, Uibo R, Haller-Kikkatalo K. MicroRNA profiling of second trimester maternal plasma shows upregulation of miR-195-5p in patients with gestational diabetes. Gene 2018;672:137-42.

21. Pheiffer C, Dias S, Rheeder P, Adam S. Decreased expression of circulating miR-20a-5p in South African women with gestational diabetes mellitus. Mol Diagn Ther 2018;22:345-52.

22. Joglekar MV, Joglekar VM, Hardikar AA. Expression of isletspecific microRNAs during human pancreatic development. Gene Expr Patterns 2009;9:109-13.

23. Correa-Medina M, Bravo-Egana V, Rosero S, Ricordi C, Edlund H, Diez J, et al. MicroRNA miR-7 is preferentially expressed in endocrine cells of the developing and adult human pancreas. Gene Expr Patterns 2009;9:193-9.

24. Accili D, Talchai SC, Kim-Muller JY, Cinti F, Ishida E, Ordelheide AM, et al. When $\beta$-cells fail: lessons from dedifferentiation. Diabetes Obes Metabol 2016;18:117-22.

25. Sebastiani G, Grieco G, Brusco N, Ventriglia G, Formichi C, Marselli $\mathrm{L}$, et al. MicroRNA expression analysis of in vitro dedifferentiated human pancreatic islet cells reveals the activation of the pluripotency-related microRNA cluster miR-302s. Int J Mol Sci 2018;19:1170.

26. Guay C, Regazzi R. New emerging tasks for microRNAs in the control of $\beta$-cell activities. Biochim Biophys Acta 2016;1861:2121-29.

27. Tattikota SG, Rathjen T, McAnulty SJ, Wessels HH, Akerman I, et al. Argonaute2 mediates compensatory expansion of the pancreatic $\beta$-cell. Cell Metabol 2014;19:122-34.

28. Latreille M, Herrmanns K, Renwick N, Tuschl T, Malecki MT, McCarthy MI, et al. miR-375 gene dosage in pancreatic b-cells: implications for regulation of $\beta$-cell mass and biomarker development. J Mol Med 2015;93:1159-69.

29. Feng J, Xing W, Xie L. Regulatory roles of microRNAs in diabetes. Int J Mol Sci 2016;17:1729.

30. Li ZY, Na HM, Peng G, Pu J, Liu P. Alteration of microRNA expression correlates to fatty acid-mediated insulin resistance in mouse myoblasts. Mol Biosyst 2011;7:871-7.

31. Wei R, Yang J, Liu GQ, Gao MJ, Hou WF, Zhang L, et al. Dynamic expression of microRNAs during the differentiation of human embryonic stem cells into insulin-producing cells. Gene 2013; 518:246-55 
32. Kredo-Russo S, Ness A, Mandelbaum AD, Walker MD, Hornstein E. Regulation of pancreatic microRNA-7 expression. Exp Diabetes Res 2012;2012. https://doi.org/10.1155/2012/ 695214.

33. Zhao C, Dong J, Jiang T, Shi Z, Yu B, Zhu Y, et al. Early secondtrimester serum miRNA profiling predicts gestational diabetes mellitus. PloS One 2011;6:e23925.

34. Cao YL, Jia YJ, Xing BH, Shi DD, Dong XJ. Plasma microRNA-16 $-5 p,-17-5 p$ and $-20 a-5 p$ : novel diagnostic biomarkers for gestational diabetes mellitus. J Obstet Gynaecol Res 2017;43:

974-81.

35. Pheiffer C, Dias S, Rheeder P, Adam S. screening for gestational diabetes mellitus: the potential of microRNAs. In: Gestational diabetes dellitus-an overview with some recent advances: IntechOpen; 2018.

36. Rosero S, Bravo-Egana V, Jiang Z, Khuri S, Tsinoremas N, Klein D, et al. MicroRNA signature of the human developing pancreas. BMC Genom 2010;11:509. 